\section{Commentary: Destination zero stroke: Three steps, but one at a time}

\author{
James Tatoulis, AM, MBBS, MS, MD, FRACS, \\ FCSANZ
}

Stroke is the most devastating complication of coronary artery bypass grafting (CABG) - many would say even worse than death! Its frequency, although reduced by advances such as preoperative computed tomography scans, epiaortic ultrasonography, avoiding side-biting clamps, using connecting devices, and single-clamp techniques, is still $0.8 \%$ to $2 \%$. $^{1}$ Avoiding the ascending aorta completely is a logical strategy, supported by mounting evidence. ${ }^{2}$

Vallely and colleagues ${ }^{3}$ offer a further, definitive advance toward completely eliminating stroke in CABG. They present the rationale ("why"). The "when" is logical. If there is a technique superior to others that one uses for the most challenging situations-the "hostile" aorta, it is rational to use this technique routinely rather than occasionally, and then attempt it in the most stressful situations. To master such a technique, one should use it often, as the default, and question why it should not be used. Necessarily, other strategies will be more appropriate for marked cardiomegaly, urgent situations, hemodynamic instability, etc.

The technical aspects of "how" are addressed by other articles and videos. The authors recognize the discomfort of many surgeons of having only one vascular input and base their techniques predominantly on the 2 in-situ internal thoracic arteries (ITAs) to guarantee a greater myocardial blood supply. Additionally, there is less chance of technical misadventure with

\footnotetext{
From the Department of Cardiothoracic Surgery, Royal Melbourne Hospital; and Department of Surgery, University of Melbourne, Melbourne, Australia. Disclosures: The author reported no conflicts of interest.

The Journal policy requires editors and reviewers to disclose conflicts of interest and to decline handling or reviewing manuscripts for which they may have a conflict of interest. The editors and reviewers of this article have no conflicts of interest.

Received for publication Oct 6, 2021; revisions received Oct 6, 2021; accepted for publication Oct 8, 2021; available ahead of print Oct 13, 2021.

Address for reprints: James Tatoulis, AM, MBBS, MS, MD, FRACS, FCSANZ, Department of Cardiothoracic Surgery, Medical Centre, Royal Melbourne Hospital, Suite 28, 300 Grattan St, Parkville, Australia, 3050 (E-mail: james.tatoulis@ mh.org.au).

JTCVS Techniques 2021;10:149-50

2666-2507

Copyright (C) 2021 The Author(s). Published by Elsevier Inc. on behalf of The American Association for Thoracic Surgery. This is an open access article under the CC BY-NC-ND license (http://creativecommons.org/licenses/by-nc-nd/4.0/).

https://doi.org/10.1016/j.xjtc.2021.10.014
}

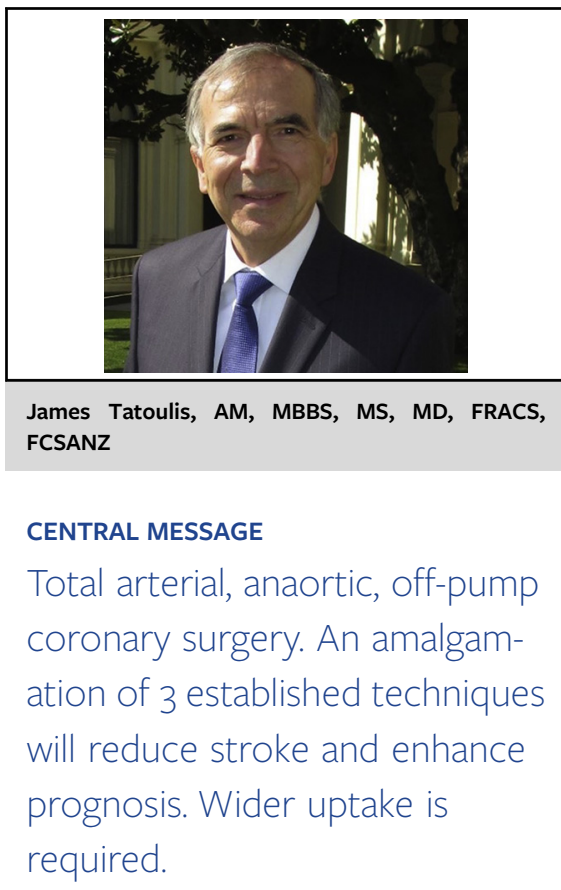

the left ITA, especially at the left ITA-Y anastomosis, and possible distortion, or vascular steal.

The main issue is the second part of the "how," coupled with "who!" How to institute this operation widely, beyond a few centers? Vallely and colleagues ${ }^{3}$ propose the ideal operation with 3 components to achieve all the goals of myocardial revascularization-zero mortality, through avoiding cardiac ischemia, zero stroke by avoiding the aorta, the source of emboli, and the best long-term outcomes through total arterial revascularization.

Some would argue that as stroke rates are only $0.8 \%$ to $2 \%$, further reduction may well be offset by reduced graft patencies, incomplete revascularization as seen with offpump CABG (OPCAB), and a multitude of learning curve mortalities and morbidity. However, these arguments do not preclude trying and achieving.

Three hurdles need to be overcome: procuring and using multiple arterial grafts including both ITAs and radials, adoption of OPCAB techniques, and complex reconstructions with the ITAs and radials. Although each is well established in its own right, it is a matter of combining them! Thus far, these are 3 bridges too far for many surgeons, as the uptake of $\mathrm{OPCAB}$ is low, multiple arterial grafting is $<10 \%$ in most countries, and anaortic techniques are uncommon. ${ }^{4}$

As CABG will continue to be the most common operation performed by cardiac surgeons, all cardiac surgeons should 
be trained in such techniques rather than having a "subspecialty" of coronary surgery. ${ }^{5}$ For anaortic techniques to have traction, specific programs need to be devised and "owned" by our professional associations. Methods to achieve this are addressed by the authors, especially more comprehensive training, adopted incrementally, in all aspects of CABG. Realistically, most surgeons will not adopt these techniques unless they have seen them, performed them under supervision, and become comfortable with them.

A way forward may be for the professional societies to fund surgeons for periods of at least 3 months to attend centers at which anaortic techniques are standard, learn and perform these operations under guidance, then return to their institution, invested in the benefit of these techniques so that they may institute them and teach them to others.
Only with such encouragement and planning will we be able to cross each of these 3 bridges-total arterial, off-pump, and anaortic - for the benefit of our patients.

\section{References}

1. Head SJ, Milojevic M, Daemen J, Ahn JM, Boersma E, Christiansen EH, et al. Stroke rates following surgical versus percutaneous 323 coronary revascularization. J Am Coll Cardiol. 2018;72:386-98.

2. Zhao DF, Edelman JJ, Seco M, Bannon PG, Wilson MK, Byrom MJ, et al. Coronary artery bypass grafting with and without manipulation of the ascending aorta: a network meta-analysis. J Am Coll Cardiol. 2017;69:924-36.

3. Vallely MP, Seco M, Ramponi F, Puskas JD. Total-arterial, anaortic, off-pump coronary artery surgery: why, when, and how. J Thorac Cardiovasc Surg Tech. 2021;10:140-8.

4. Gaudino M, Chikwe J, Falk V, Lawton JS, Puskas JD, Taggart DP. Transatlantic editorial. The use of multiple arterial grafts for coronary revascularization in Europe and North America. J Thorac Cardiovasc Surg. 2020;109:1631-6.

5. Mack M, Taggart DP. Coronary revascularization should be a subspecialty focus in cardiac surgery. J Thorac Cardiovasc Surg. 2019;157:945-7. 